http://ejournal.undip.ac.id/index.php/kapal

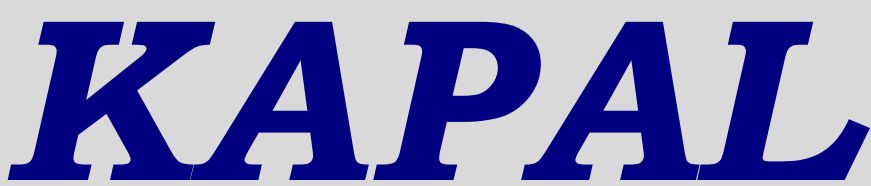

\title{
Analisa Turbin Tipe H-Rotor Guna Meningkatkan Output Daya Listrik Pada Perencanaan Pembangunan PLTAL Di Selat Pantar
}

\author{
Karno R. Malau ${ }^{l)}$, Untung Budiarto ${ }^{l)}$, Eko Sasmito Hadi ${ }^{l)}$ \\ ${ }^{1)}$ Departemen Teknik Perkapalan, Fakultas Teknik, Universitas Diponegoro \\ Jl. Prof. Soedarto, SH, Kampus Undip Tembalang, Semarang, Indonesia 5027
}

diajukan pada $: 10 / 04 / 18 \quad$ direvisi pada $: 15 / 05 / 18 \quad$ diterima pada $: 28 / 05 / 18$

\begin{abstract}
Abstrak
Permintaan (demand) energi di Indonesia cenderung meningkat pesat sejalan dengan pertumbuhan ekonomi dan pertambahan penduduk. Sebagian besar kebutuhan tenaga listrik di Indonesia masih dipasok dari pembangkit listrik berbahan bakar fosil (tidak dapat diperbaharui), perlu pemanfaatan energi terbarukan sebagai solusi memenuhi kebutuhan listrik nasional, salah satunya PLTAL (Pembangkit Listrik Tenaga Arus Laut). Pada penelitian ini dilakukan studi desain dan analisa pemilihan turbin untuk PLTAL dengan membandingkan kelebihan dan kekurangan turbin jenis H-Rotor dengan beberapa variasi. Penelitian ini memvariasikan jumlah blade dan sudut serang blade dengan kecepatan arus laut masing-masing 2,5 m/detik, 2,75 m/detik dan 3,1 m/detik. Turbin yang digunakan adalah turbin dengan profil foil NACA 0015, panjang span $1600 \mathrm{~mm}$, diameter turbin $1600 \mathrm{~mm}$ dan panjang chord turbin $300 \mathrm{~mm}$. Penelitian ini menggunakan metode CFD dan perhitungan menngunakan empiris. Dari hasil penelitian ini diperoleh turbin yang paling optimum untuk digunakan pada pembangkit listrik tenaga arus ialah turbin H-Rotor dengan jumlah blade 4 yang memiliki sudut serang 50. Nilai Output yang dimiliki sebesar 8,024 kW (pada 2,5 m/s), 10,632 kW (pada 2,75 m/s), dan 15,142 kW (pada 3,1 m/s). Nilai Cp (Power Coeffcient) terbesar tiap kecepatan arus laut dimiliki oleh turbin dengan variasi jumlah blade 3 buah dengan sudut serang $5^{\circ}$ sebesar 0,273 (pada 2,5 m/s), 0,271 (pada 2,75 $\mathrm{m} / \mathrm{s}$ ), dan 0,270 (pada 3,1 m/s). Sedangkan nilai Efisiensi (\%) terkecil tiap kecepatan inlet dimiliki oleh turbin dengan variasi jumlah blade 2 buah dengan sudut serang $0^{\circ}$ sebesar $12,4 \%$ (pada 2,5 $\mathrm{m} / \mathrm{s}$ ), 12,237\% (pada 2,75 m/s), dan $12,04 \%($ pada $3,1 \mathrm{~m} / \mathrm{s})$.
\end{abstract}

Copyright $\odot$ 2018, KAPAL, 1829-8370 (p), 2301-9069(e)

Kata Kunci : Turbin, Arus Laut, Blade, H-Rotor, CFD

\section{PENDAHULAN}

Permintaan (demand) energi di Indonesia cenderung meningkat pesat sejalan dengan pertumbuhan ekonomi dan pertambahan penduduk. Berdasarkan data PT Perusahaan Listrik Negara (PLN), permintaan akan energi listrik terus meningkat dari tahun ke tahun. Sampai tahun 2009, sebagian besar kebutuhan tenaga listrik di Indonesia masih dipasok dari pembangkit listrik berbahan bakar fosil. Minyak Bumi masih menduduki peringkat tertinggi, yaitu 51,66\%; gas alam menduduki tingkat kedua, yakni

\footnotetext{
*) Penulis Korespondensi :

Email : karnormalau@gmail.com
}

28,57\%; sisanya dipasok dari energi minyak sebesar 15,34\% dan energi terbarukan 4,43\% [1].

Ketergantungan terhadap konsumsi energi berbahan bakar fosil dan belum termanfaatkannya sumber energi baru terbarukan merupakan salah satu kelemahan dalam menerapkan pemerataan kebijakan energi. Padahal ketersediaan sumber energi terbarukan di Indonesia sangat melimpah, yaitu energi gelombang dan energi arus air laut yang belum termanfaatkan dengan baik.

Sebelum membahas mengenai energi arus laut, beberapa peneliti memanfaatkan energi gelombang laut untuk menghasilkan listrik, diantaranya adalah [2] [3], dimana energi gelombang laut tersebut dimanfaatkan 
menggunakan OWC. Kemudian peneliti lain mendesain geometri konverter gelombang air laut untuk menjadi listrik dengan bentuk segi empat [4], segi enam [5] dan segi delapan [6].

Sedangkan untuk penelitian mengenai pemanfaatan energi arus laut telah dilakukan oleh [7] dalam hal variasi bentuk sudu, sudut serang dan kecepatan arus untuk mendapatkan daya maksimal yang dihasilkan. Kemudian pengaruh perubahan panjang chord dan ketebalan blade pada turbin PLTAL juga dikaji oleh [8]. Dalam penelitiannya [9], Kecepatan arus pasang-surut di perairan Indonesia umumnya lebih kecil dari 1,5 $\mathrm{m} /$ det. Kecuali di selat-selat diantara pulau-pulau Bali, Lombok, dan Nusa Tenggara Timur, dimana kecepatannya bisa mencapai 2,5 - 3,0 m/det. Dengan demikian, beberapa perairan selat terutama di kawasan timur Indonesia merupakan wilayah yang cukup prospek sebagai lokasi pemanfaatan energi arus laut, salah satu di antaranya daerah penelitian di Selat Pantar - Nusa Tenggara Timur. Kecepatan arus di atas 1,5 m/det dengan durasi antara $8-10 \mathrm{jam} / \mathrm{hari}$ berpotensi untuk dimanfatkan sebagai pembangkit listrik tenaga arus laut (PLTAL). Area yang paling potensial untuk pengembangan pembangkit listrik tenaga arus laut yang disarankan Marine Current Turbine Ltd. adalah yang mempunyai nilai kecepatan minimum $2 \mathrm{~m} /$ detik - 2,5 m/detik [10].

Teknologi arus air dibagi dalam dua kategori yaitu Axial Flow Turbine dan Cross Flow Turbine. Turbin horizontal axis berputar terhadap sumbu horizontalnya, Jenis turbin ini dibagi menjadi 2 , yaitu straight axis turbine dan inclined. Sementara vertical axis turbine dibagi menjadi 3 jenis turbin yaitu, savonnius turbine, darrieus turbine dan H-Rotor turbine. Ketiga jenis turbin itu dibedakan berdasarkan jenis blade-nya [11].

Pemilihan desain yang terbaik dari PLTAL sangat perlu dilakukan, supaya ketika PLTAL telah dibangun dapat menghasilkan energi yang optimal dan juga harapannya tidak terjadi kerugian yang sia - sia.

Pada penelitian ini akan dilakukan studi desain dan analisa pemilihan turbin untuk PLTAL dengan membandingkan kelebihan dan kekurangan turbin jenis $H$-Rotor dengan variasi jumlah blade dan sudu serang untuk mencari daya yang paling maksimal serta bentuk dan desain $H$ Rotor yang menghasilkan torsi dan daya yang paling tinggi. Penelitian ini termasuk dalam sekup pemanfaatan energi arus laut. Namun, penelitian ini terbatas pada analisa performa turbin $\mathrm{H}$-Rotor untuk meningkatkan daya yang dihasilkan.

\section{METODE}

Metode penelitian menggunakan pendekatan software, sehingga prosedur yang harus dilakukan adalah mempersiapkan data-data teknis untuk kemudian dilakukan pemodelan dan analisa.

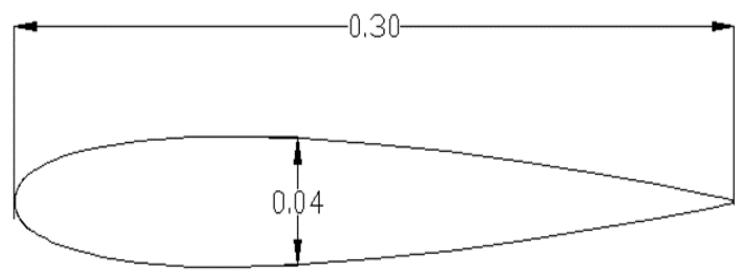

Gambar 1. Geometri foil NACA 0015

Tahapan yang dilakukan pada pengolahan data dimulai yaitu : Tahap pertama yang dilakukan adalah tahap mecari offset data profil blade NACA0015, tahap kedua adalah desain Turbin dengan bantuan Software Rhinocerros 4.0, tahap ketiga adalah melakukan analisa dibantu software komputer Ansys CFX 14, tahapan keempat adalah menentukan desain yang paling optimum, tahap kelima adalah membuat model dengan Print 3D.

Berikut adalah tabulasi ukuran utama model turbin yang akan dianalisa:
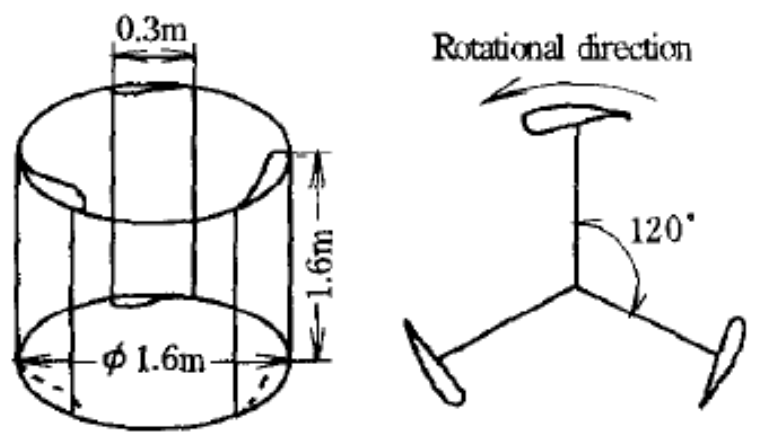

Gambar 2. Geometri turbin acuan

Tabel 1. Parameter tetap desain turbin H-Rotor

\begin{tabular}{ccc}
\hline No & \multicolumn{2}{c}{ Parameter Tetap } \\
\hline 1 & Geometry Foil & NACA 0015 \\
2 & Diameter Turbin $(\mathrm{mm})$ & 1600 \\
3 & hub diameter $(\mathrm{mm})$ & 50 \\
4 & Blade span $(\mathrm{mm})$ & 1600 \\
5 & Blade chord $(\mathrm{mm})$ & 300 \\
\hline
\end{tabular}

\subsection{Pembuatan Model Turbin H-Rotor}

Geometri foil pada turbin merupakan salah satu parameter yang menentukan besarnya daya yang dapat dibangkitkan oleh pembangkit listrik 
tenaga arus laut. Semakin optimal desain dari sebuah turbin maka akan meningkatkan efisiensi pembangkit listrik itu sendiri. Pada penelitian ini penulis memvariasikan model awal menjadi beberapa variasi Variasi model turbin H-Rotor dapat dilihat dalam tabel berikut:

Tabel 2. Model Variasi Turbin

\begin{tabular}{ccc}
\hline No. & \multicolumn{2}{c}{ Variasi Turbin } \\
\hline 1. & Blade Number & 2,3 dan 4 \\
2. & Sudut sudu $(\mathrm{mm})$ & $0^{0}$, dan $5^{0}$ \\
3. & Kecepatan Arus $(\mathrm{m} / \mathrm{s})$ & $2,5,2.75 \& 3,1$ \\
\hline
\end{tabular}

Desain turbin yang dikembangkan adalah turbin dengan sudu serang 0 derajat dengan jumlah blade 3 buah dengan ukuran geometri seperti Tabel 2 dan selanjutnya divariasikan untuk meningkatkan output daya yang turbin.

\subsection{Diagram Alir}

Pada penelitian ini langkah-langkah penelitian mengacu pada diagram alir pada Gambar 3:

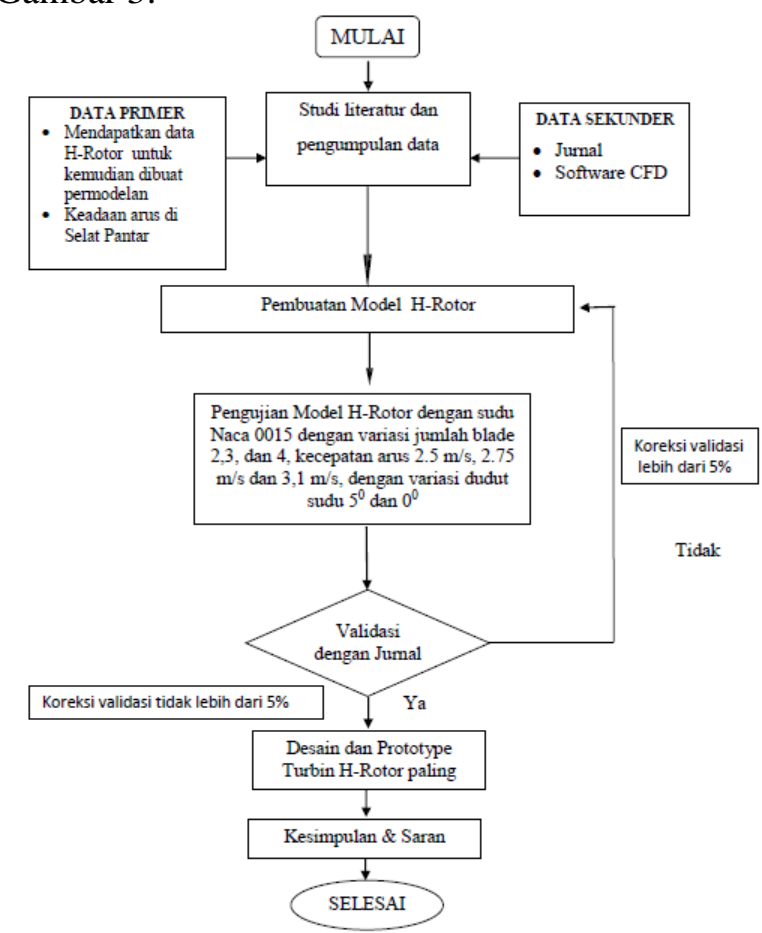

. Gambar 3. Diagram Alir (Flowchart)

Hasil gambar desain turbin kemudian dianalisa dengan bantuan software Ansys CFX 14.0 untuk mendapatkan nilai gaya (force) yang diterima turbin pada saat dikenai arus dengan kecepatan 2,5 m/det, 2,75 m/det dan 3,1 m/det.
Pemilihan arus ini berdasarkan data arus maksimum dari P3GL yang tertera pada Tabel 3.

Tabel 3. Data Arus Selat di Provinsi NTT

\begin{tabular}{ccccc}
\hline $\begin{array}{c}\text { Nama } \\
\text { Selat }\end{array}$ & Lombok & $\begin{array}{c}\text { Nusa } \\
\text { Penida }\end{array}$ & $\begin{array}{c}\text { Larant } \\
\text { uka }\end{array}$ & Pantar \\
\hline $\begin{array}{c}\text { Kec. Arus } \\
(\mathrm{m} / \mathrm{s})\end{array}$ & $1,8-2,4$ & $0,5-3,2$ & $1,5-3,4$ & $1,5-3,1$ \\
\hline
\end{tabular}

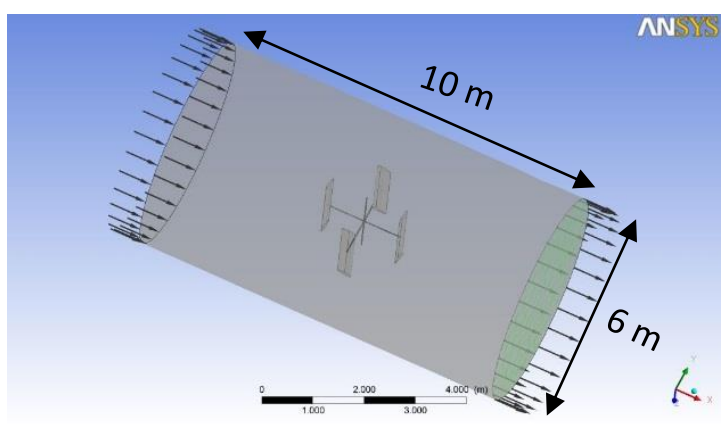

Gambar 4. Simulasi pre-post CFD dengan Ansys CFX 14 untuk mendapat nilai force

Tabel 4. Model Variasi Turbin

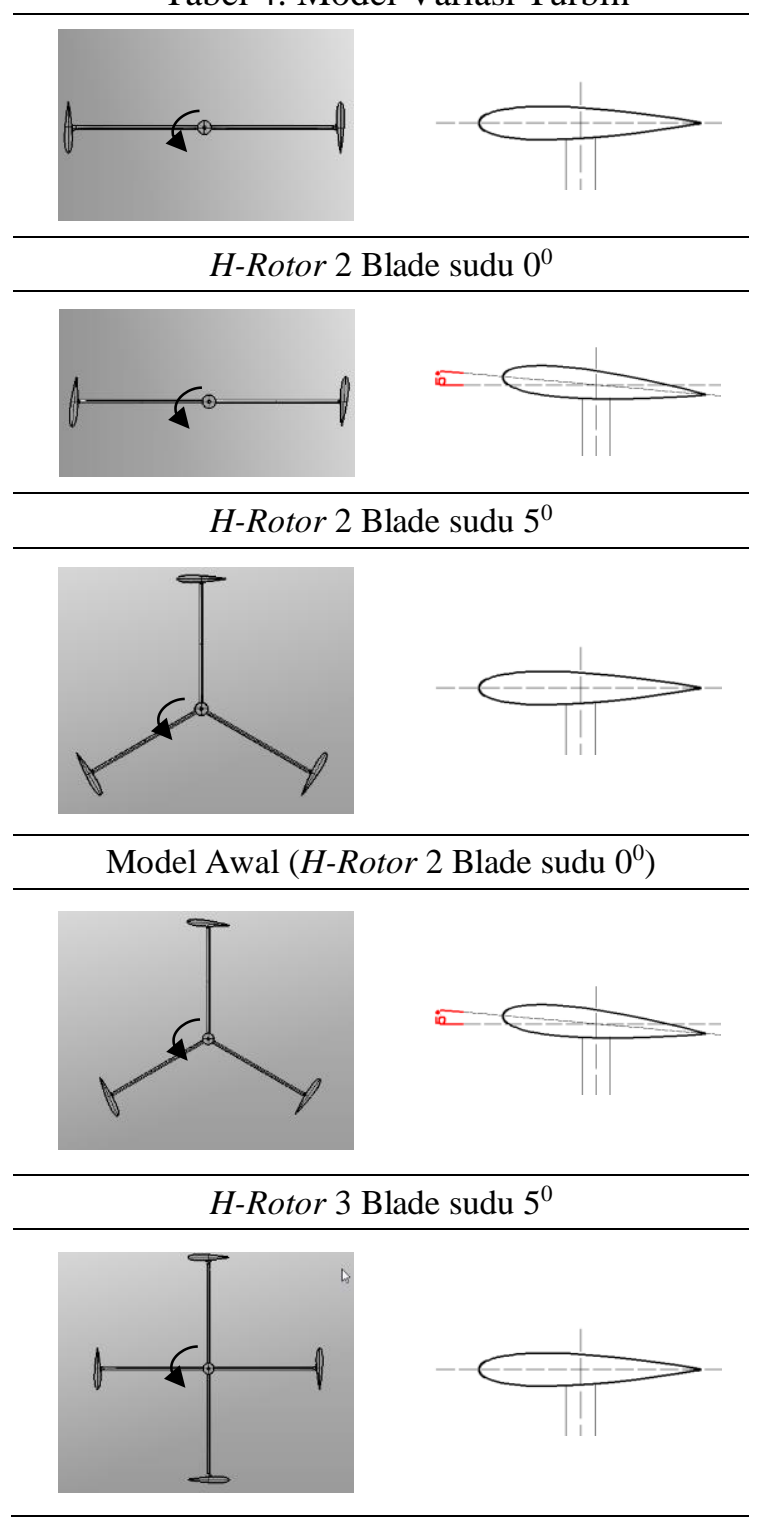




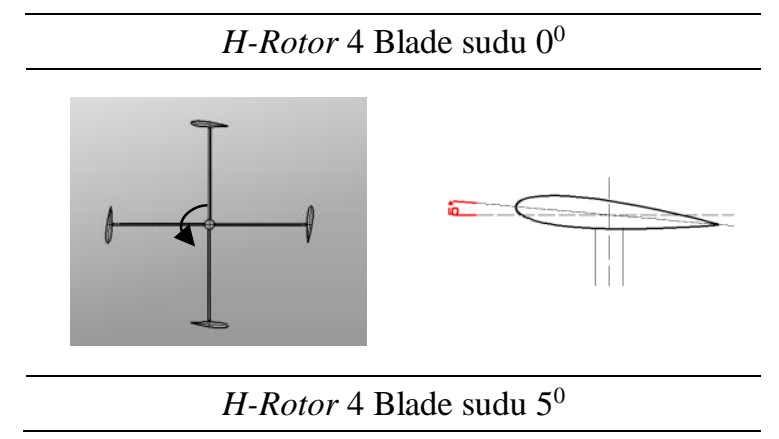

\section{HASIL DAN PEMBAHASAN}

Hasil pemodelan dari Rhinocerros sesuai dengan variasi jumlah blade 2, 3 dan 4 dengan masing-masing variasi sudut serang 00 dan 50 kemudia dianalisa dengan software CFD. Hasil analisa didapat force (gaya) yang diterima turbin ketika dikenai arus laut dengan variasi kecepatan $2,5 \mathrm{~m} / \mathrm{det}, 2,75 \mathrm{~m} /$ det dan $3,1 \mathrm{~m} /$ det.

Tabel 5. Nilai Gaya Pada Analisa dengan Ansys

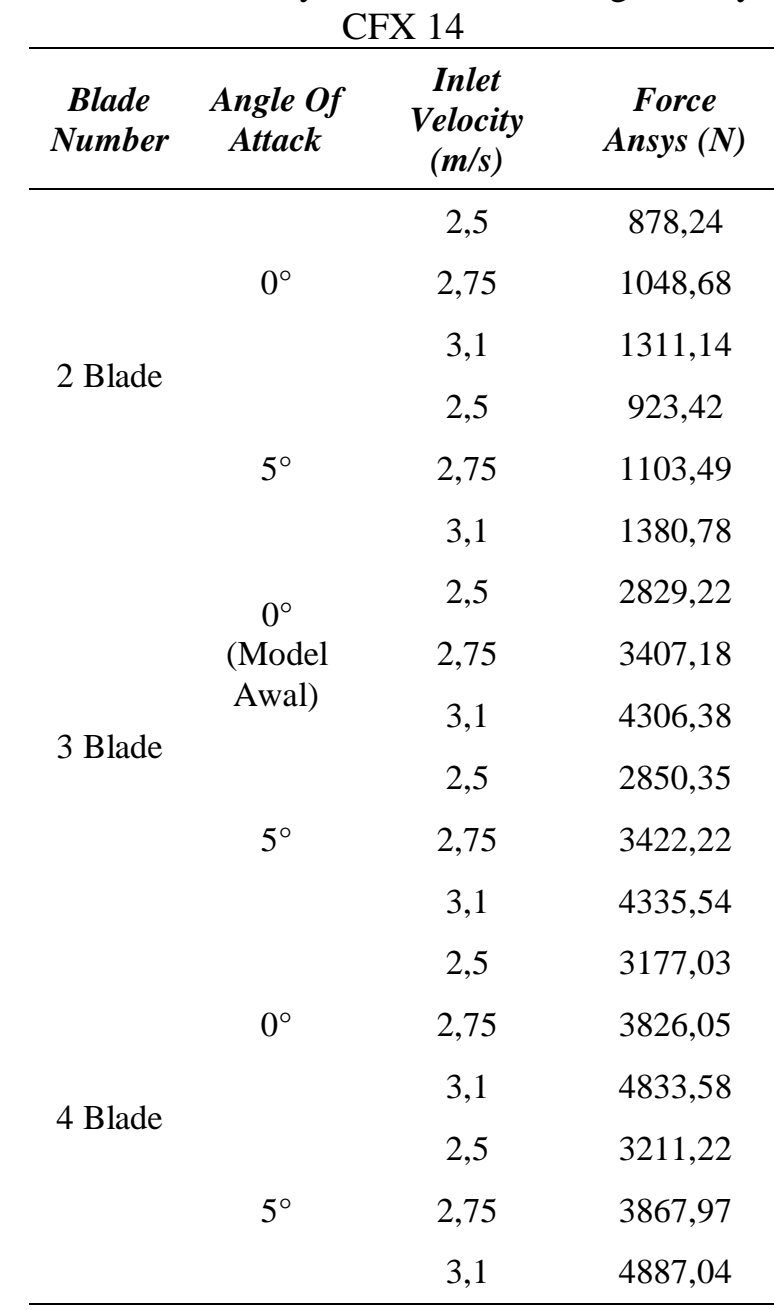

Mengacu Tabel 5, nilai gaya terbesar tiap kecepatan inlet dimiliki oleh Turbin dengan 4 Blade dengan sudut serang $5^{\circ}$ sebesar 3211,22 N (pada 2,5 m/s), 3867,97 $\mathrm{N}$ (pada 2,75 m/s), dan $4887,04 \mathrm{~N}$ (pada $3,1 \mathrm{~m} / \mathrm{s}$ ).

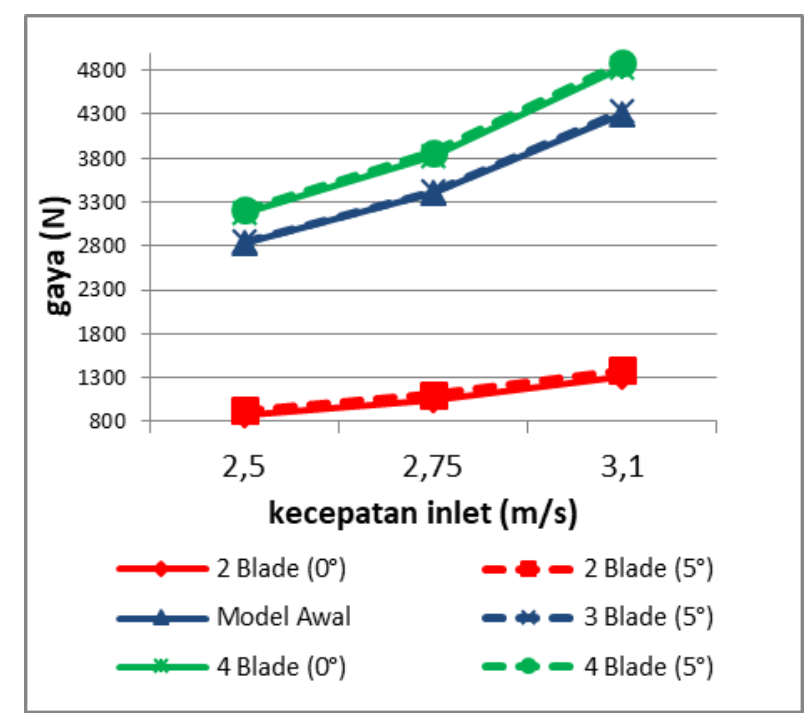

Gambar 5. Grafik Hubungan gaya dengan kecepatan inlet pada variasi jumlah blade dan sudu

\subsection{Perhitungan Torsi Turbin}

Dinyatakan dengan persamaan:

$$
\mathrm{Q}=\mathrm{F} \varnothing \mathrm{x} \mathrm{R}(N \cdot m)
$$

Dimana Q adalah Torsi (Nm), Fø adalah Gaya Tangensial (N), R adalah Jari-jari (m).

Turbin arus H-Rotor dengan jumlah 2 blade yang memiliki sudut serang $0^{\circ}$ pada kecepatan arus $2,5 \mathrm{~m} / \mathrm{s}$, maka perhitungan nilai torsinya yaitu :

$$
\begin{aligned}
\mathrm{Q} & =\mathrm{F} \varnothing \times \mathrm{R} \\
& =878,24 \times 0,8 \\
& =702,592 \mathrm{Nm}
\end{aligned}
$$

\begin{tabular}{|c|c|c|c|}
\hline $\begin{array}{c}\text { Blade } \\
\text { Number }\end{array}$ & $\begin{array}{c}\text { Angle } \\
\text { Of } \\
\text { Attack }\end{array}$ & $\begin{array}{c}\text { Inlet } \\
\text { Velocity } \\
\left(\mathrm{m} / \mathrm{s}^{2}\right)\end{array}$ & $\begin{array}{c}\text { Torque } \\
\text { (Nm) }\end{array}$ \\
\hline \multirow{6}{*}{2 Blade } & \multirow{4}{*}{$0^{\circ}$} & 2.5 & 702.592 \\
\hline & & 2.75 & 838.944 \\
\hline & & 3.1 & 1048.912 \\
\hline & & 2.5 & 738.736 \\
\hline & \multirow[t]{2}{*}{$5^{\circ}$} & 2.75 & 882.792 \\
\hline & & 3.1 & 1104.624 \\
\hline \multirow{3}{*}{3 Blade } & \multirow{3}{*}{$\begin{array}{c}0^{\circ} \\
\text { (Model } \\
\text { Awal) }\end{array}$} & 2.5 & 2263.376 \\
\hline & & 2.75 & 2725.744 \\
\hline & & 3.1 & 3445.104 \\
\hline
\end{tabular}

Tabel 6. Hasil Perhitungan Torsi (Torque) 


\begin{tabular}{cccc} 
& 2.5 & 2280.28 \\
& $5^{\circ}$ & 2.75 & 2737.776 \\
& & 3.1 & 3468.432 \\
& & 2.5 & 2541.624 \\
& $0^{\circ}$ & 2.75 & 3060.84 \\
& & 3.1 & 3866.864 \\
& & 2.5 & 2568.976 \\
& $5^{\circ}$ & 2.75 & 3094.376 \\
& & 3.1 & 3909.632 \\
\hline
\end{tabular}

Mengacu Tabel 6, nilai Torsi terbesar tiap kecepatan inlet dimiliki oleh Turbin H-Rotor dengan sudut serang $5^{\circ}$ sebesar 2568,967 $\mathrm{Nm}$ (pada 2,5 m/s), 3094,378 Nm (pada 2,75 m/s), dan $3909,632 \mathrm{Nm}$ (pada 3,1 m/s).

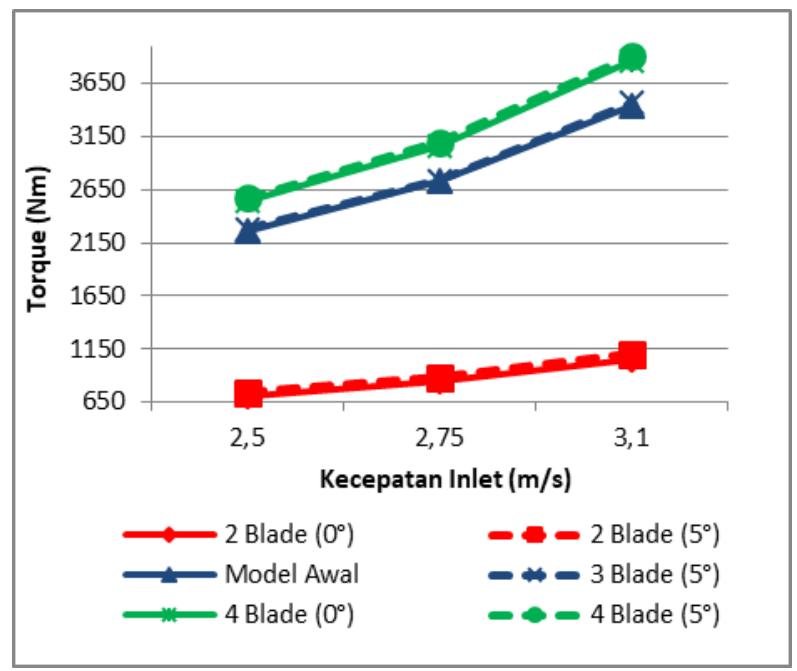

Gambar 6. Hubungan torsi dengan kecepatan inlet pada variasi jumlah blade dan sudu serang

\subsection{Perhitungan Daya, Efisiensi dan Cp}

Besarnya daya yang dihasilkan oleh Turbin arus vertical axis merupakan energi poros yang diperoleh turbin dari energi aliran arus air.Daya turbin dapat diperoleh dari Persamaan 2:

$$
\mathrm{Pt}=\mathrm{Q} \times \omega \quad(\text { watt })
$$

Dimana Pt adalah Daya turbin (watt), Q adalah Torsi turbin $(\mathrm{Nm})$ dan $\omega$ adalah kecepatan sudut ( $\mathrm{Rad} / \mathrm{s})$. Untuk menghitung daya turbin, kita harus terlebih dahulu mengetahui kecepatan sudut turbin. Kecepatan sudut turbin diperoleh berdasarkan nilai Tip Speed Ratio (TSR). TSR merupakan perbandingan antara kecepatan putar turbin terhadap kecepatan arus. TSR dilambangkan dengan $\lambda$ seperti pada Persamaan 3 .

$$
\lambda=\frac{\omega \times R}{V}
$$

Contoh perhitungan daya pada turbin 2 blade dengan kecepatan arus $2,5 \mathrm{~m} /$ det dengan sudu serang $0^{0}$ yaitu:

$$
\begin{aligned}
\mathrm{Pt}=\mathrm{Q} & \times \omega \\
& =702,592 \times 3,125 \\
& =2,197 \mathrm{Kw}
\end{aligned}
$$

\begin{tabular}{|c|c|c|c|}
\hline $\begin{array}{c}\text { Jumlah } \\
\text { Blade }\end{array}$ & $\begin{array}{c}\text { Angle } \\
\text { Of } \\
\text { Attack }\end{array}$ & $\begin{array}{c}\text { Inlet } \\
\text { Velocity } \\
\left(\mathrm{m} / \mathrm{s}^{2}\right)\end{array}$ & $\begin{array}{c}\text { Output } \\
\text { Power } \\
\text { (kW) }\end{array}$ \\
\hline \multirow{6}{*}{2 Blade } & \multirow{3}{*}{$0^{\circ}$} & 2.5 & 2.194 \\
\hline & & 2.75 & 2.882 \\
\hline & & 3.1 & 4.062 \\
\hline & \multirow{3}{*}{$5^{\circ}$} & 2.5 & 2.307 \\
\hline & & 2.75 & 3.033 \\
\hline & & 3.1 & 4.278 \\
\hline \multirow{6}{*}{3 Blade } & \multirow{3}{*}{$\begin{array}{c}0^{\circ} \\
\text { (Model } \\
\text { Awal) }\end{array}$} & 2.5 & 7.069 \\
\hline & & 2.75 & 9.365 \\
\hline & & 3.1 & 13.343 \\
\hline & \multirow{3}{*}{$5^{\circ}$} & 2.5 & 7.122 \\
\hline & & 2.75 & 9.406 \\
\hline & & 3.1 & 13.433 \\
\hline \multirow{6}{*}{4 Blade } & \multirow{3}{*}{$0^{\circ}$} & 2.5 & 7.939 \\
\hline & & 2.75 & 10.516 \\
\hline & & 3.1 & 14.976 \\
\hline & \multirow{3}{*}{$5^{\circ}$} & 2.5 & 8.024 \\
\hline & & 2.75 & 10.632 \\
\hline & & 3.1 & 15.142 \\
\hline
\end{tabular}

Tabel 7. Kecepatan Sudut Turbin tiap variasi inlet

\begin{tabular}{ccccc}
$\begin{array}{c}\text { Inlet } \\
\text { Velocity } \\
(\mathbf{m} / \mathbf{s})\end{array}$ & $\begin{array}{c}\text { Jari } \\
\text { jari } \\
(\mathbf{m})\end{array}$ & $\begin{array}{c}\text { Tip } \\
\text { Speed } \\
\text { Ratio }\end{array}$ & $\begin{array}{c}\text { Kecepatan } \\
\text { sudut } \\
(\mathbf{r a d} / \mathbf{s})\end{array}$ & $\begin{array}{c}\mathbf{R P M} \\
(\mathbf{1} \mathbf{~ r m = 0 . 1 0 4 7} \\
\mathbf{r a d} / \mathbf{s})\end{array}$ \\
\hline 2,5 & 0,8 & 1,00 & 3.125 & 29.84 \\
2,75 & 0,8 & 1,00 & 3.437 & 32.82 \\
3.1 & 0,8 & 1,00 & 3,875 & 37.00 \\
\hline
\end{tabular}

Tabel 8. Hasil Perhitungan Output Power 
Mengacu Tabel 8, nilai Output Power terbesar tiap kecepatan inlet dimiliki oleh turbin dengan jumlah blade 4 dengan sudut serang $5^{\circ}$ sebesar 8,024 kW (pada 2,5 m/s), 10,632 kW (pada $2,75 \mathrm{~m} / \mathrm{s}$ ), dan $15,142 \mathrm{~kW}$ (pada $3,1 \mathrm{~m} / \mathrm{s}$ ).

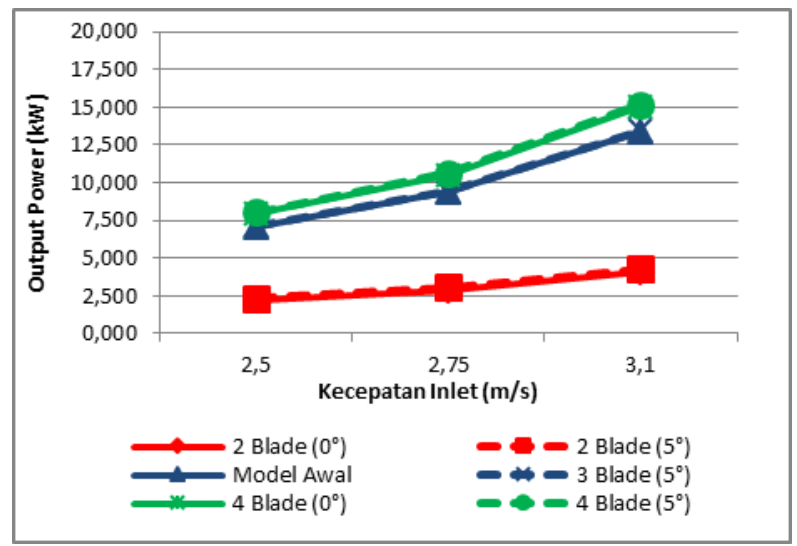

Gambar 7. Hubungan Output Power dengan kecepatan inlet pada variasi jumlah blade, dan sudut serang

Nilai koefisien power dapat dihitung dengan menggunakan Persamaan 4 berikut :

$$
\mathrm{C}_{p}=\frac{Q \times \omega}{0,5 \times \rho \times V^{3} \times A}
$$

Untuk menentukan efesiensi sebuah turbin terlebih dahulu mengetahui besar power yang yang masuk ke turbin tersebut. Besar power yang masuk ke turbin dapat dicari dengan Persamaan 5.

$$
P h=1 / 2 \rho(A v) v 2
$$

\begin{tabular}{|c|c|c|c|}
\hline $\begin{array}{c}\text { Blade } \\
\text { Number }\end{array}$ & $\begin{array}{c}\text { Angle Of } \\
\text { Attack }\end{array}$ & $\begin{array}{c}\text { Inlet } \\
\text { Velocity } \\
(\mathrm{m} / \mathrm{s} 2)\end{array}$ & $\begin{array}{c}\text { Water } \\
\text { Power } \\
(k W)\end{array}$ \\
\hline \multirow{6}{*}{2 Blade } & \multirow{4}{*}{$0^{\circ}$} & 2.5 & 17.697 \\
\hline & & 2.75 & 23.555 \\
\hline & & 3.1 & 33.742 \\
\hline & & 2.5 & 17.697 \\
\hline & \multirow[t]{2}{*}{$5^{\circ}$} & 2.75 & 23.555 \\
\hline & & 3.1 & 33.742 \\
\hline \multirow{4}{*}{3 Blade } & \multirow{3}{*}{$\begin{array}{c}0^{\circ} \\
\text { (model } \\
\text { awal) }\end{array}$} & 2.5 & 26.105 \\
\hline & & 2.75 & 34.746 \\
\hline & & 3.1 & 49.773 \\
\hline & $5^{\circ}$ & 2.5 & 26.105 \\
\hline
\end{tabular}

Tabel 9. Perhitungan Daya Air (Ph)

\begin{tabular}{cccc}
\hline & & 2.75 & 34.746 \\
& 3.1 & 49.773 \\
& & 2.5 & 34.514 \\
& $0^{\circ}$ & 2.75 & 45.938 \\
& & 3.1 & 65.805 \\
& & 2.5 & 34.514 \\
& $5^{\circ}$ & 2.75 & 45.938 \\
& & 3.1 & 65.805 \\
\hline
\end{tabular}

Berdasarkan Tabel 9 nilai daya masuk tertinggi terjadi pada turbin H-Rotor Turbine kecepatan aliran $3,1 \mathrm{~m} / \mathrm{s}$ sebesar $65,80 \mathrm{~kW}$. Sehingga perhitungan efisiensi turbin Arus $\mathrm{H}$ Rotor Turbine pada variasi jumlah blade 2 buah, kecepatan aliran $2,5 \mathrm{~m} / \mathrm{s}$ dengan sudut serang $0^{\circ}$ :

$$
\begin{aligned}
(\eta t) & =P t / P h \times 100 \% \\
& =2,194 / 17,697 \times 100 \% \\
& =12,40 \%
\end{aligned}
$$

Tabel 10. Hasil Perhitungan Power Coeffcient dan

\begin{tabular}{ccccccc}
\hline $\begin{array}{c}\text { Bla } \\
\text { de } \\
\text { Nu } \\
\text { m. }\end{array}$ & $\begin{array}{c}\text { Angle } \\
\text { of } \\
\text { Attack }\end{array}$ & $\begin{array}{c}\text { Inlet } \\
\text { Vel. } \\
\left(\boldsymbol{m} / \mathbf{s}^{2}\right)\end{array}$ & $\begin{array}{c}\text { Eh } \\
(\text { Daya } \\
\text { Turbin } \\
\text { ) }\end{array}$ & $\begin{array}{c}\text { Pt } \\
(\text { Daya } \\
\text { Air })\end{array}$ & Cp & $\begin{array}{c}\text { Efisie } \\
\text { nsi } \\
(\%)\end{array}$ \\
& & 2.5 & 2.194 & 17.697 & 0.12 & 12.40 \\
& $0^{\circ}$ & 2.75 & 2.882 & 23.555 & 0.12 & 12.23 \\
2 & & 3.1 & 4.062 & 33.742 & 0.12 & 12.04 \\
& & 2.5 & 2.307 & 17.697 & 0.13 & 13.03 \\
& $5^{\circ}$ & 2.75 & 3.033 & 23.555 & 0.12 & 12.87 \\
& & 3.1 & 4.278 & 33.742 & 0.12 & 12.67 \\
& $0^{\circ}$ & 2.5 & 7.069 & 26.105 & 0.27 & 27.08 \\
& $($ model & 2.75 & 9.365 & 34.746 & 0.27 & 26.94 \\
& awal) & 3.1 & 13.343 & 49.773 & 0.26 & 26.80 \\
& & 2.5 & 7.122 & 26.105 & 0.27 & 27.28 \\
& $5^{\circ}$ & 2.75 & 9.406 & 34.746 & 0.27 & 27.07 \\
& & 3.1 & 13.433 & 49.773 & 0.27 & 26.98 \\
& & 2.5 & 7.939 & 34.514 & 0.23 & 23.00 \\
& $0^{\circ}$ & 2.75 & 10.516 & 45.938 & 0.22 & 22.89 \\
4 & & 3.1 & 14.976 & 65.805 & 0.22 & 22.75 \\
& & 2.5 & 8.024 & 34.514 & 0.23 & 23.24 \\
& $5^{\circ}$ & 2.75 & 10.632 & 45.938 & 0.23 & 23.14 \\
& & 3.1 & 15.142 & 65.805 & 0.23 & 23.01 \\
\hline & & & & & &
\end{tabular}

Mengacu Tabel 10 Nilai Cp terbesar tiap kecepatan inlet dimiliki oleh turbin dengan variasi jumlah blade 3 buah dengan sudut serang $5^{\circ}$ sebesar 0,273 (pada 2,5 m/s), 0,271 (pada 2,75 $\mathrm{m} / \mathrm{s}$ ), dan 0,270 (pada $3,1 \mathrm{~m} / \mathrm{s}$ ). Sedangkan nilai 
Efisiensi (\%) terkecil tiap kecepatan inlet dimiliki oleh turbin dengan variasi jumlah blade 2 buah dengan sudut serang $0^{\circ}$ sebesar $12,4 \%$ (pada 2,5 $\mathrm{m} / \mathrm{s}$ ), $12,237 \%$ (pada $2,75 \mathrm{~m} / \mathrm{s}$ ), dan $12,04 \%$ (pada $3,1 \mathrm{~m} / \mathrm{s}$ ).

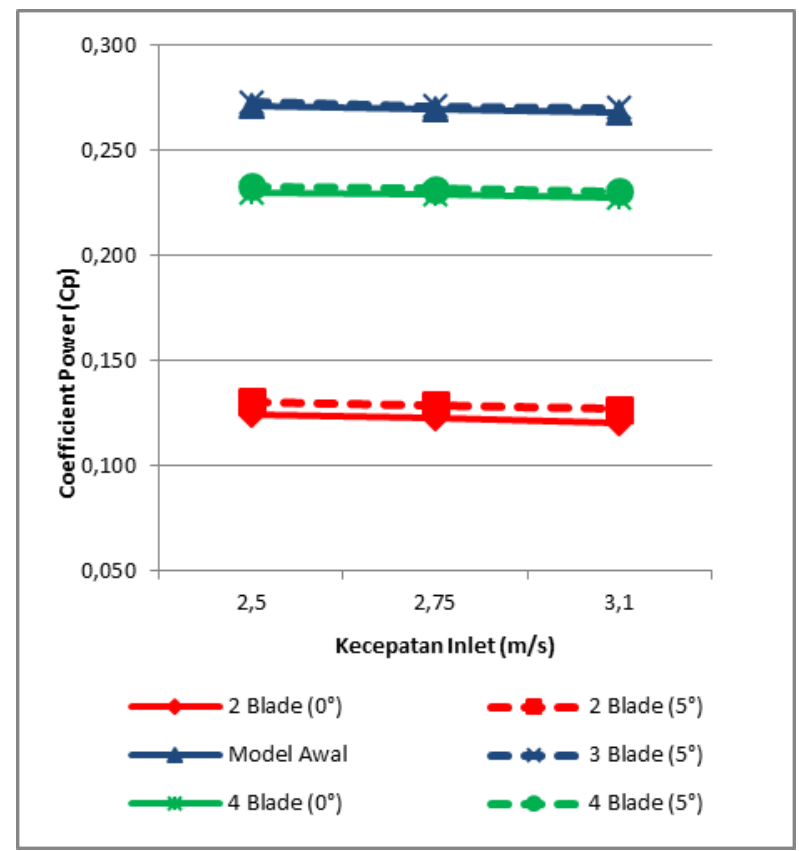

Gambar 8. Hubungan Coefficient Power dengan kecepatan inlet pada variasi jumlah blade dan sudut serang.

Berdasarakan hasil analisa Ansys CFX 14 nilai force terbesar tiap kecepatan inlet dimiliki oleh Turbin dengan 4 Blade dengan sudut serang $5^{\circ}$ sebesar 3211,22 $\mathrm{N}$ (pada 2,5 m/s), 3867,97 $\mathrm{N}$ (pada $2,75 \mathrm{~m} / \mathrm{s}$ ), dan 4887,04 N (pada $3,1 \mathrm{~m} / \mathrm{s}$ ).

Nilai Torque terbesar tiap kecepatan inlet dimiliki oleh Turbin $H$-Rotor dengan sudut serang $5^{\circ}$ sebesar 2568,967 Nm (pada 2,5 m/s), 3094,378 $\mathrm{Nm}$ (pada 2,75 m/s), dan 3909,632 Nm (pada 3,1 $\mathrm{m} / \mathrm{s})$.

Nilai Output daya terbesar tiap kecepatan inlet dimiliki oleh turbin dengan jumlah blade 4 dengan sudut serang $5^{\circ}$ sebesar $8,024 \mathrm{~kW}$ (pada $2,5 \mathrm{~m} / \mathrm{s}$ ), 10,632 kW (pada 2,75 m/s), dan 15,142 $\mathrm{kW}$ (pada $3,1 \mathrm{~m} / \mathrm{s}$ ).

Nilai Ouput daya turbin meningkat sebesar $1,799 \mathrm{~kW}$ atau $13,5 \%$ pada desain turbin 4 blade sudu serang $0^{0}$ dengan power sebesar $15,142 \mathrm{~kW}$ dari desain awal 3 blade 00 dengan nilai ouput sebesar 13,433 kW.

Nilai Power Coefficient dan Efisiensi (\%) terbesar tiap kecepatan inlet dimiliki oleh turbin dengan variasi jumlah blade 3 buah dengan sudut serang $5^{\circ}$ sebesar 0,273 (pada 2,5 m/s), 0,271 (pada $2,75 \mathrm{~m} / \mathrm{s}$ ), dan 0,270 (pada $3,1 \mathrm{~m} / \mathrm{s}$ ). Sedangkan nilai Efisiensi (\%) terkecil tiap kecepatan inlet dimiliki oleh turbin dengan variasi jumlah blade 2 buah dengan sudut serang $0^{\circ}$ sebesar 12,4\% (pada $2,5 \mathrm{~m} / \mathrm{s}$ ), 12,237\% (pada $2,75 \mathrm{~m} / \mathrm{s})$, dan $12,04 \%$ (pada $3,1 \mathrm{~m} / \mathrm{s})$.

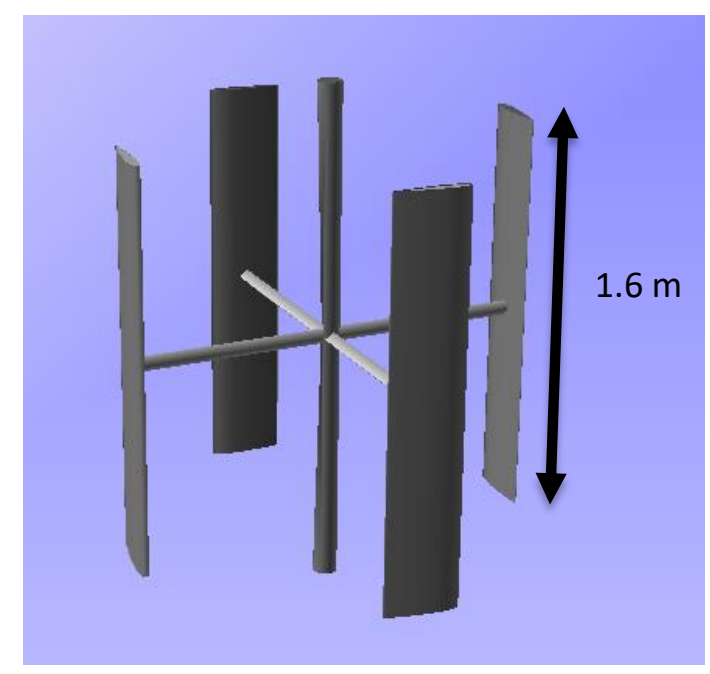

(a)

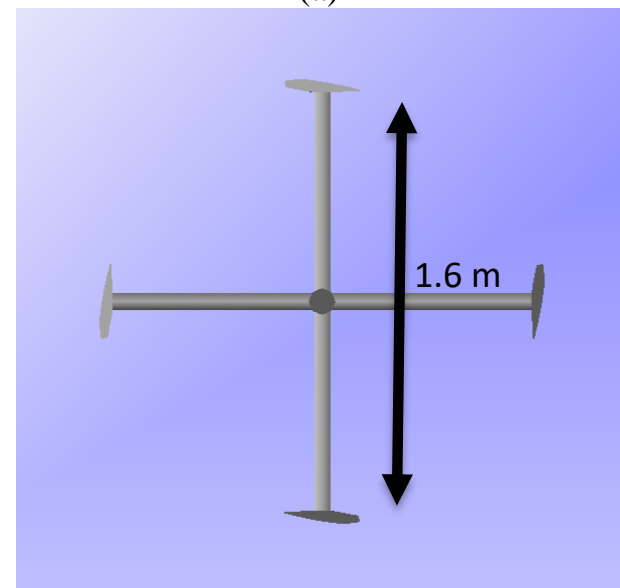

(b)

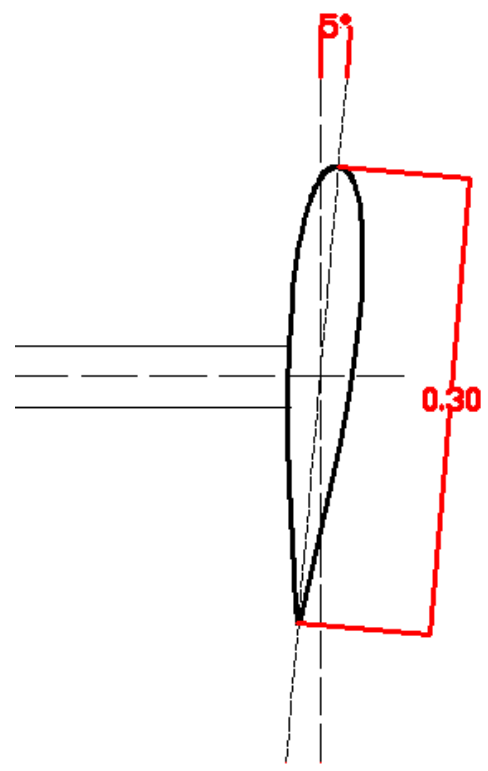

(c)

Gambar 9. Desain dan Geometri Turbin H-Rotor paling optimum 


\subsection{Validasi Metode Penelitian}

Validasi perhitungan dikakukan dengan menggunakan software Ansys CFX 14 yaitu dengan cara membandingkan hasil perhitungan CFD dengan hasil H-Darrieus Wind Turbine dengan power $7 \mathrm{~kW}$ berpenampang airfoil NACA 00203 sudu dengan spesifikasi berikut.

Tabel 11. Spesifikasi Turbin validasi

\section{Vertical Axis Turbine Dimension}

\begin{tabular}{cc}
\hline Geometri Foil & NACA0015 \\
Rotor diamater & $6000(\mathrm{~mm})$ \\
Rotor height & $6000(\mathrm{~mm})$ \\
Blade Number & $2(\mathrm{buah})$ \\
Blade lenght & $6000(\mathrm{~mm})$ \\
RPM & 125 \\
\hline
\end{tabular}

Perhitungan nilai torsi didapatkan dari hasil kali gaya tangensial dengan jari-jari pada setiap sudu seperti pada Persamaan 1.

Tabel 12. Tabel Koreksi Validasi

\begin{tabular}{ccc}
\hline & $\begin{array}{c}\text { Daya Turbin } \\
(\mathbf{k W})\end{array}$ & $\begin{array}{c}\text { Prosentase } \\
\text { Error }(\%)\end{array}$ \\
\hline Acuan & 7 & - \\
CFD & 6,78 & 3,1 \\
\hline
\end{tabular}

\section{KESIMPULAN}

Dari hasil analisa yang telah dilakukan pada setiap variasi Turbin Arus Tipe H-Rotor dengan jumlah blade 2,3 dan 4 buah serta sudut serang $0^{\circ}$ ; $5^{\circ}$ serta kecepatan arus $2,5 \mathrm{~m} / \mathrm{s} ; 2,75 \mathrm{~m} / \mathrm{s} \& 3,1$ $\mathrm{m} / \mathrm{s}$, maka disimpulkan desain dan geometri turbin H-Rotor yang paling sesuai untuk digunakan di Selat Pantar yaitu: Geometri turbin paling sesuai yaitu H-Rotor dengan jenis NACA 0015, jumlah blade 4 dan sudu serang $5^{0}$. Daya output yang dihasilkan sebesar 8,024 kW (pada $2,5 \mathrm{~m} / \mathrm{s}$ ), 10,632 kW (pada 2,75 m/s), dan 15,142 $\mathrm{kW}$ (pada 3,1 m/s) dengan nilai Cp 0,233(pada 2,5 m/s), 0,232 (pada 2,75 m/s), dan 0,230 (pada $3,1 \mathrm{~m} / \mathrm{s})$. Nilai Ouput daya turbin meningkat sebesar $1,799 \mathrm{~kW}$ atau $13,5 \%$ pada desain turbin 4 blade dengan sudu serang $0^{0}$ dari desain awal. Berdasarakan hasil perhitungan Nilai Power Coefficient dan Efisiensi (\%) terbesar tiap kecepatan inlet dimiliki oleh turbin dengan variasi jumlah blade 3 buah dengan sudut serang $5^{\circ}$ sebesar 0,273 (pada 2,5 m/s), 0,271 (pada 2,75 $\mathrm{m} / \mathrm{s}$ ), dan 0,270 (pada $3,1 \mathrm{~m} / \mathrm{s}$ ).

\section{UCAPAN TERIMA KASIH}

Terima kasih kepada LPPM dan BEM Undip yang sudah membantu dalam penelitian ini berupa dukungan moril dan mendanai penelitian ini.

\section{DAFTAR PUSTAKA}

[1] A. Assagaf, "Analisis Faktor-Faktor Yang Mempengaruhi Permintaan Tenaga Listrik Konsumen Sektor Konsumtif Perusahaan Listrik Negara," Ekuitas Jurnal Ekonomi dan Keuangan, vol. 4, no. 3, pp. 330-349, 2010.

[2] B. Prasetyo, D. Chrismianto dan M. Iqbal, "Analisa Pengaruh Geometri dan Jumlah Sudu Terhadap Performa Wells Turbine," Jurnal Teknik Perkapalan, vol. 3, no. 4, 2015.

[3] M. B. N. Royyana, U. Budiarto dan G. Rindo, "ANALISA BENTUK OSCILLATING WATER COLUMN UNTUK PEMANFAATAN GELOMBANG LAUT SEBAGAI SUMBER ENERGI TERBARUKAN DENGAN METODE COMPUTATIONAL FLUID DYNAMIC ( CFD )," Jurnal Teknik Perkapalan, vol. 3, no. $1,2015$.

[4] E. S. Rizki, E. S. Hadi dan Kiryanto, "DESAIN KONVERTER GELOMBANG BENTUK SEGI EMPAT SEBAGAI SUMBER PEMBANGKIT LISTRIK DI PERAIRAN LAUT JAWA," Jurnal Teknik Perkapalan, vol. 4, no. 2, 2016.

[5] W. N. Mustikojati, E. S. Hadi dan Kiryanto, "DESAIN KONVERTER GELOMBANG BENTUK SEGIENAM SEBAGAI SUMBER PEMBANGKIT LISTRIK DI PERAIRAN LAUT JAWA," Jurnal Teknik Perkapalan, vol. 4, no. 2, 2016.

[6] M. Sidiq, E. S. Hadi dan Kiryanto, "DESAIN KONVERTER GELOMBANG BENTUK SEGI DELAPAN SEBAGAI SUMBER PEMBANGKIT LISTRIK DI PERAIRAN LAUT JAWA," Jurnal teknik Perkapalan, vol. 4, no. 2, 2016.

[7] D. Oktavianto, U. Budiarto dan Kiryanto, "Analisa Pengaruh Variasi Bentuk Sudu, Sudut Serang dan Kecepatan Arus Pada Turbin Arus Tipe Sumbu Vertikal Terhadap 
Daya yang Dihasilkan Oleh Turbin," Jurnal Teknik Perkapalan, vol. 5, no. 2, 2017.

[8] R. Andriawan dan A. Trimulyono, "ANALISA PENGARUH PERUBAHAN PANJANG CHORD DAN KETEBALAN BLADE PADA TURBIN PEMBANGKIT TENAGA ARUS DENGAN METODE CFD," Jurnal Teknik Perkapalan, vol. 1, no. $1,2013$.

[9] A. Yuningsih, "Potensi Arus Laut untuk Pembangkit Energi Baru Terbarukan di Selat Pantar, Nusa Tenggara Timur.," Majalah Mineral dan Energi, vol. 9, no. 1, pp. 61-72, 2011.

[10] P. L. Fraenkel , "Power from marine currents," Proceedings of the Institution of Mechanical Engineers, Part A: Journal of Power and Energy, vol. 216, pp. 1-14, 2002.

[11] F. Rivantoro dan I. S. Arief, "Studi Pemilihan Desain Pembangkit Listrik Tenaga Arus Laut (PLTAL) Menggunakan Metode Analytical Hierarchy Process (AHP)," Jurnal Teknik ITS, vol. 4, no. 2, pp. B114-B118, 2016. 